\title{
Crystal Structure of the Higher Temperature Phase (Type B) of Cyclic Trimer of Poly(ethylene terephthalate)
}

\author{
Yukishige Kitano and Tamaichi Ashida* \\ Toray Research Center, Inc., \\ Sonoyama, Otsu, Shiga 520, Japan \\ * Faculty of Engineering, Nagoya University, \\ Chikusa, Nagoya 464, Japan
}

(Received April 6, 1992)

\begin{abstract}
The crystal structure of one of meta-stable forms of the higher temperature phase (Type B) of cyclic trimer of poly(ethylene terephthalate) was determined at room temperature as a part of our study on conformational differences between the lower temperature phase (Type A) and Type B. The structure of Type B is found to be dimensionally similar to that of Type A but differs significantly in crystal structure and conformation. The higher temperature phase of tris(ethylene terephthalate), $\mathrm{C}_{30} \mathrm{H}_{24} \mathrm{O}_{12}, M_{r}=576.49$, crystallizes in the hexagonal space group $P 6_{1}$ (or $P 6_{5}$ ), with $a=15.316(1), c=20.756(2) \AA, Z=6, V=4216.4 \AA^{3}, D_{\mathrm{c}}=1.363$, and $D_{\mathrm{m}}=1.351$ $\mathrm{mg} \mathrm{m}^{-3}$ at $298 \mathrm{~K}$. The final $R$ was 0.085 for 1636 observed reflections $\left(F_{\mathrm{o}}>3 \sigma\left(F_{\mathrm{o}}\right)\right)$. The molecule of Type B has approximate $m\left(C_{\mathrm{s}}\right)$ symmetry, the pseudo-mirror plane lying on one of the benzene rings $(\mathrm{C}(2)-\mathrm{C}(7))$ and passing perpendicularly through the mid-point of one of ethylenic bonds $(\mathrm{C}(19)-\mathrm{C}(20))$. The macrocycle ring is more flat than the ring of Type $\mathrm{A}$. Three equivalent benzene rings are nearly pallarel to the mean plane of all atoms in the molecule, the dihedral angles of the benzene ring plane to the mean plane of all of atoms being $8.6^{\circ}, 5.6^{\circ}$, and $7.9^{\circ}$. Three ethylene glycol chains have the gauche conformation with independent torsion angles being $66.6^{\circ}, 80.7^{\circ}$, and $-56.4^{\circ}$. A significant shortening of the $C_{s p} 3-C_{s p} 3$ bond of the ethylene glycol chains is observed as generally found in $n$-methylene dibenzoate derivatives.
\end{abstract}

KEY WORDS Crystal Structure / Oligomer / Cyclic Trimer / Cyclic Tris(ethylene terephthalate) / Higher Temperature Phase / Poly(ethylene terephthalate) /

Oligomers from fiber- and film-forming polycondensates have been much investigated not only from analytical points but also from the structural interests as they serve as useful model compounds for corresponding polymers. ${ }^{1}$ Information of cyclic trimers of poly(ethylene terephthalate), PET, is extensive because of their industrial importance as cyclic trimers found in greatest aboundance in equilibrium with molten PET present an undesirable natural impurity in industrial products such as fibers and films. ${ }^{2-12}$ For instance the oligometric powders cause blurs in dyeing of fibers or drop-out of recording on the magnetic tapes, when they breed out on the surface of fibers or films.

The crystal structure of the lower temperature phase (Type $\mathrm{A}^{* 1}$ ) of cyclic trimer of PET was reported by Haśek et al. at first on the basis of acentric space group $C c^{13}$ and then recalculated by them by the space group of $C 2 / c$ with the molecule lying on a two-fold axis of the crystal. ${ }^{14}$ At the same time we presented independently the crystal structures of two modifications of cyclic trimer of PET, Type $\mathrm{A}$, and higher temperature phase (Type $\mathrm{B}^{* 1}$ )

${ }^{* 1}$ Type A and Type B, designated by Binns et al., ${ }^{7}$ are stable at low and high temperatures respectively. The transition point of Type A to Type $B$ is about $200^{\circ} \mathrm{C}$. 
at room temperature after preliminary work. ${ }^{15-17}$ In this paper we describe the crystal structure of one of meta-stable forms of Type B, determined at room temperature and discuss the geometrical and conformational differences between the two modifications. This paper is one part of our studies on crystal structures of oligomers of poly(ethylene terephtalate), ${ }^{18}$ poly(butylene terephthalate), ${ }^{19}$ and nylon $6 / 12$ copolymer. ${ }^{20}$

\section{EXPERIMENTAL}

\section{Materials and Method}

The crystals of Type B were grown by vaccum sublimation above $200^{\circ} \mathrm{C}$ from Type A powders extracted from a piece of commercial PET film. Crystals obtained are colorless dipyramidal hexagonal plates with the dimensions of up to 4 to $5 \mathrm{~mm}$ long. The crystals of Type B are stable at room temperature in dry air. ${ }^{17}$

The unit-cell parameters were refined by least-squares fit of 15 reflections measured on a diffractometer. The density was measured by floatation in a zinc chlolide solution. A crystal with dimensions of $0.2 \times 0.25 \times 0.3 \mathrm{~mm}^{3}$ was used for the data collection. The crystal data are summarized in Table I.

\section{Data Collection}

Data collection was carried out on a Rigaku automated four-circle diffractometer employing graphite-monochromated $\mathrm{Cu}-K_{\alpha}$ radiation. Intensities were measured at room temperature, using the $2 \theta-\omega$ scan mode with the range of $(0.90+0.142 \tan \theta)^{\circ}$ in $\omega$. The scan speed and background counting time were $10^{\circ} / \mathrm{min}$ and $2 \mathrm{~s}$ at each terminus of the scans for reflections with $2 \theta<80^{\circ}, 5^{\circ} / \mathrm{min}$ and $4 \mathrm{~s}$ for $80^{\circ} \leq 2 \theta<110^{\circ}$ and $2^{\circ} / \mathrm{min}, 8 \mathrm{~s}$ for $110^{\circ} \leq 2 \theta<$ $128^{\circ}$. No significant changes were observed in the intensities of the three standard reflections measured periodically during data collection. A total of 5267 reflections were measured yielding 2698 independent reflections, of which
Table I. Crystal data of Type B of cyclic tris(ethylene terephthalate) measured at $298 \mathrm{~K}$

\begin{tabular}{|c|c|}
\hline Chemical formula & $\mathrm{C}_{30} \mathrm{H}_{24} \mathrm{O}_{12}$ \\
\hline Molecular weight & 576.49 \\
\hline Crystal system & Hexagonal \\
\hline Space group & $P 6_{1}\left(\right.$ or $\left.P 6_{5}\right)$ \\
\hline Cell constants & $\begin{array}{l}a=15.316(1) \AA \\
c=20.756(2)\end{array}$ \\
\hline Volume of the unit-cell & $V=4216.4(5) \AA^{3}$ \\
\hline Density & \\
\hline Calcd & $1.363 \mathrm{mg} \mathrm{m}^{-3}$ \\
\hline Obsd & $1.351 \mathrm{mg} \mathrm{m}^{-3}$ \\
\hline $\begin{array}{l}\text { Number of molecules in } \\
\text { the unit cell }\end{array}$ & $Z=6$ \\
\hline $\begin{array}{l}\text { Number of electrons in } \\
\text { the unit cell }\end{array}$ & $F(000)=1800$ \\
\hline Absorption coefficient & $\mu=9.02 \mathrm{~cm}^{-1}$ (for $\left.\mathrm{Cu}-K_{\alpha}\right)$ \\
\hline
\end{tabular}

1636 were regarded as observable by the criterion of $F_{\mathrm{o}}>3 \sigma\left(F_{\mathrm{o}}\right)$. Corrections were made for Lorentz and polarization effects but not that for absorption.

\section{Structure Determination}

The structure was solved by direct methods using the program MULTAN. ${ }^{21}$ The positions of carbon and oxygen atoms of telephthalate moiety were readily located by the first E map and after preliminary refinement the hydrogen atoms bonded to those atoms were also located. Difference electron-density maps indicated the most probable sites for carbon atoms of ethylene moiety, but with additional smaller peaks in this region which represented alternative atomic sites. Attempts were made to refine various models of the distorted region with partial occupation of atomic sites. All gave large thermal parameters and unsatisfactory bond lengths and angles, indicating considerable conformational disorder structure. Eventually it was decided to restrict calculation to the simplest model, using only the largest peaks for the disordered carbon atoms to specify the major component of the conformational mixture and fixing the occupation parameters of all the atoms at 1.0. Hydrogen atoms in the 
disordered region were placed on calculated positions and included in structure calculations but were not refined. In the refinement, the function minimized was $\sum \omega\left(\left|F_{\mathrm{o}}\right|-\left|F_{\mathrm{c}}\right|\right)^{2}$ with $\omega=\left[\sigma^{2}\left(F_{\mathrm{o}}\right)+a\left|F_{\mathrm{o}}\right|+b\left|F_{\mathrm{o}}\right|^{2}\right]^{-1}$ where $\sigma\left(F_{\mathrm{o}}\right)$ is the standard deviation based on counting statistics. After anisotropic refinement of all non-hydrogen atoms and refinement including hydrogen atoms, the final full-matrix leastsquares cycle $(a=0.450, b=-0.002)$ resulted in convergence at $R=0.085$ and $\omega R=0.087$. The final $\Delta \rho_{\max }$ was 0.45 and $\Delta \rho_{\min }$ was $-0.30 \mathrm{e}^{-3}$. The largest residual peaks in the final difference map were in the ethylenic regions and it was confirmed that other conformations contribute to the disordered electron density, though to a lesser extent than the model used in the calculations. However, apart from the preciseness of the geometry of the ethylenic groups, the structure of the molecule was substantially defined. The atomic scattering factors were taken from Internationl Tables for X-Ray Crystallography. ${ }^{22}$ All calculations were performed with the UNICS programs $^{23}$ on a FACOM M200 computer. The positional parameters and isotropic thermal parameters for the non-hydrogen atoms are listed in Table II.*2

\section{RESULTS AND DISCUSSION}

An ORTEP ${ }^{25}$ stereoview of the Type B of cyclic trimer of PET with atom labeling is shown in Figure 1. The bond lengths and angles and selected torsion angles for the molecule are listed in Tables III and IV. The results are presented so that the three equivalent segments of the molecule can be easily compared and corresponding average distances and angles for Type $\mathrm{A}^{14}$ are added. The displacements of atoms from the benzene ring mean planes are given in Table V. For comparison, the molecular structure of Type $\mathrm{A}$ is also illustrated
Table II. Atomic parameters and temperature factors for non-hydrogen atoms ${ }^{a}$

\begin{tabular}{|c|c|c|c|c|}
\hline Atom & $x$ & $y$ & $z$ & $B_{\text {eq }} / \AA^{2}$ \\
\hline $\mathrm{O}(1)$ & $0.3692(6)$ & $0.4134(6)$ & $0.4523(8)$ & 8.1 \\
\hline $\mathrm{O}(2)$ & $0.2560(8)$ & $0.4539(6)$ & $0.4262(8)$ & 7.9 \\
\hline $\mathrm{O}(3)$ & $0.0120(5)$ & $-0.0891(5)$ & $0.4586(6)$ & 5.8 \\
\hline $\mathrm{O}(4)$ & $-0.1152(6)$ & $-0.0563(6)$ & $0.4457(7)$ & 7.2 \\
\hline $\mathrm{O}(5)$ & $0.0609(6)$ & $-0.2294(6)$ & $0.4269(8)$ & 8.9 \\
\hline $\mathrm{O}(6)$ & $0.0133(6)$ & $-0.3835(7)$ & $0.4061(9)$ & 8.6 \\
\hline $\mathrm{O}(7)$ & $0.5597(6)$ & $-0.0880(6)$ & $0.4119(8)$ & 8.0 \\
\hline $\mathrm{O}(8)$ & $0.5270(6)$ & $-0.2449(6)$ & $0.4083(7)$ & 7.4 \\
\hline $\mathrm{O}(9)$ & $0.6970(6)$ & $0.1076(5)$ & $0.4188(9)$ & 9.6 \\
\hline $\mathrm{O}(10)$ & $0.8519(5)$ & $0.2165(6)$ & $0.4187(6)$ & 6.8 \\
\hline$O(11)$ & $0.5502(7)$ & $0.4615(6)$ & $0.3952(6)$ & 7.0 \\
\hline $\mathrm{O}(12)$ & $0.7025(7)$ & $0.5816(5)$ & $0.4134(7)$ & 7.0 \\
\hline $\mathrm{C}(1)$ & $0.2772(9)$ & $0.3886(9)$ & $0.4364(10)$ & 6.2 \\
\hline $\mathrm{C}(2)$ & $0.1983(9)$ & $0.2808(8)$ & $0.4412(6)$ & 4.1 \\
\hline $\mathrm{C}(3)$ & $0.2334(9)$ & $0.2087(8)$ & $0.4490(6)$ & 4.5 \\
\hline$C(4)$ & $0.1569(7)$ & $0.1071(7)$ & $0.4514(6)$ & 3.9 \\
\hline$C(5)$ & $0.0572(8)$ & $0.0810(7)$ & $0.4503(7)$ & 4.2 \\
\hline$C(6)$ & $0.0229(9)$ & $0.1490(10)$ & $0.4428(1)$ & 6.1 \\
\hline$C(7)$ & $0.0992(9)$ & $0.2507(10)$ & $0.4418(8)$ & 5.3 \\
\hline $\mathrm{C}(8)$ & $-0.0259(7)$ & $-0.0290(8)$ & $0.4508(6)$ & 4.2 \\
\hline $\mathrm{C}(9)$ & $-0.0566(14)$ & $-0.1918(14)$ & $0.4747(13)$ & 9.1 \\
\hline$C(10)$ & $-0.0398(8)$ & $-0.2419(13)$ & $0.4210(14)$ & 9.7 \\
\hline$C(11)$ & $0.0838(9)$ & $-0.3000(10)$ & $0.4159(10)$ & 6.1 \\
\hline$C(12)$ & $0.1881(8)$ & $-0.2658(8)$ & $0.4150(6)$ & 4.1 \\
\hline$C(13)$ & $0.2637(9)$ & $-0.1667(8)$ & $0.4227(7)$ & 4.9 \\
\hline$C(14)$ & $0.3654(10)$ & $-0.1368(8)$ & $0.4169(7)$ & 4.8 \\
\hline$C(15)$ & $0.3938(8)$ & $-0.2080(7)$ & $0.4110(6)$ & 3.7 \\
\hline$C(16)$ & $0.3171(8)$ & $-0.3128(8)$ & $0.4044(5)$ & 3.8 \\
\hline$C(17)$ & $0.2177(11)$ & $-0.3387(8)$ & $0.4061(7)$ & 5.0 \\
\hline$C(18)$ & $0.4973(9)$ & $-0.1861(7)$ & $0.4135(8)$ & 5.0 \\
\hline$C(19)$ & $0.6525(14)$ & $-0.0605(11)$ & $0.4350(13)$ & 8.2 \\
\hline $\mathrm{C}(20)$ & $0.7132(11)$ & $0.0309(13)$ & $0.4000(13)$ & 9.0 \\
\hline$C(21)$ & $0.7710(10)$ & $0.2050(10)$ & $0.4176(10)$ & 5.8 \\
\hline $\mathrm{C}(22)$ & $0.7319(8)$ & $0.2736(9)$ & $0.4130(6)$ & 4.0 \\
\hline $\mathrm{C}(23)$ & $0.6332(9)$ & $0.2447(8)$ & $0.4089(8)$ & 5.3 \\
\hline $\mathrm{C}(24)$ & $0.6036(8)$ & $0.3173(9)$ & $0.4043(7)$ & 4.9 \\
\hline$C(25)$ & $0.6736(8)$ & $0.4159(7)$ & $0.4092(5)$ & 4.1 \\
\hline $\mathrm{C}(26)$ & $0.7749(7)$ & $0.4435(8)$ & $0.4137(7)$ & 4.6 \\
\hline $\mathrm{C}(27)$ & $0.8087(7)$ & $0.3758(8)$ & $0.4134(4)$ & 3.5 \\
\hline $\mathrm{C}(28)$ & $0.7470(11)$ & $0.4965(10)$ & $0.4111(8)$ & 5.4 \\
\hline $\mathrm{C}(29)$ & $0.5131(13)$ & $0.5306(11)$ & $0.4005(15)$ & 9.0 \\
\hline $\mathrm{C}(30)$ & $0.4491(9)$ & $0.5153(9)$ & $0.4581(12)$ & 7.2 \\
\hline
\end{tabular}

a $B_{\text {eq }}$ is the equivalent isotropic temperature factor calculated from the anisotropic temperature coefficients. $^{24}$

*2 The anisotropic thermal parameters of non-hydrogen atoms and positional parameters of hydrogen atoms and a list of the observed and calculated structure factors will be provided by the authors upon request. 

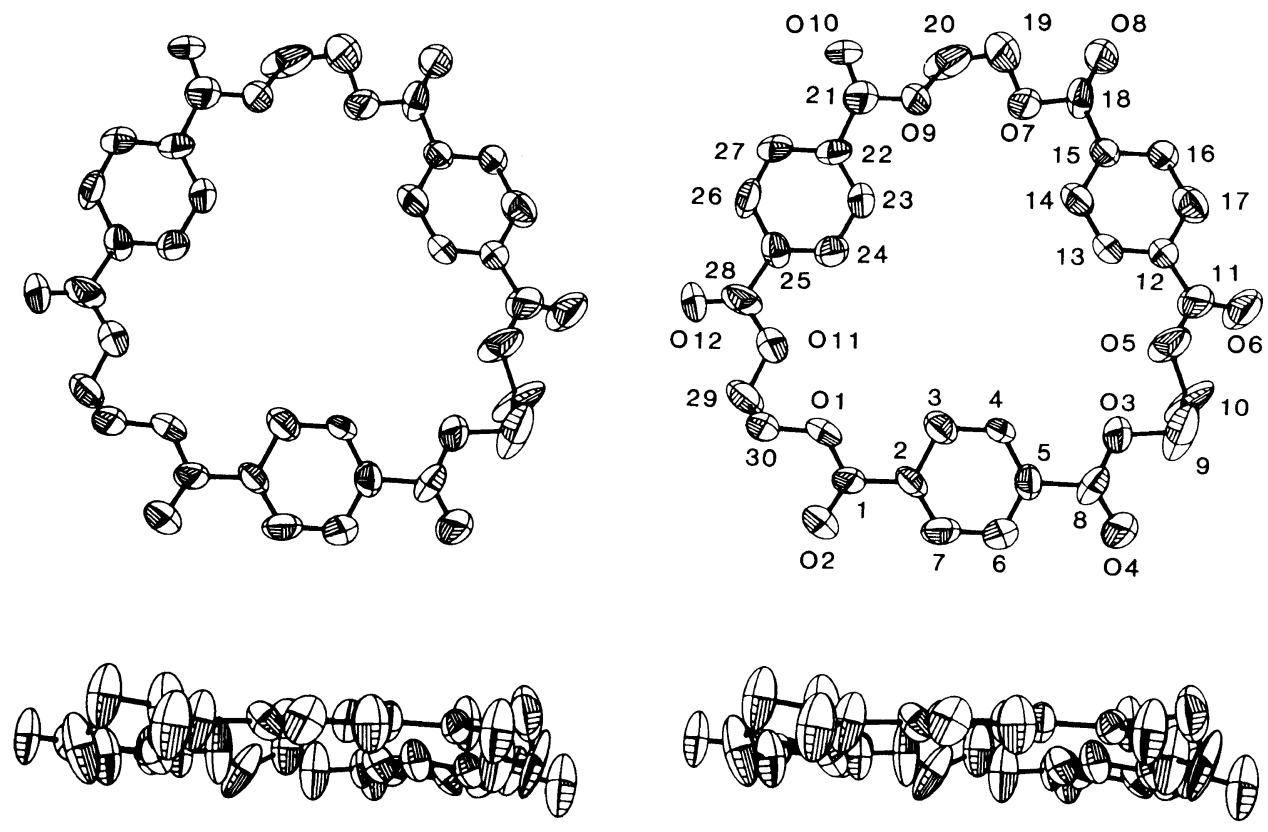

Figure 1. An ORTEP stereo drawing of the molecule of Type B with atom labelling. Thermal ellipsoids are drawn at the $50 \%$ probability level: a front view (top) and a side view (bottom).

\section{in Figure 2.}

The molecular structure of Type B consists of substantially a 30-membered macrocycle, formed by condensation of three terephthalate planar groups through ethylene linkages which act as "universal joint". The three paraphenylene groups are all cis with all the carbonyl oxygen atoms pointing outwards while the ester oxygen atoms are directed inwards of the ring system as in Type A. However, the conformation of the molecule of Type B differs significantly from Type A. The molecule of Type $\mathrm{B}$ has approximate $m\left(C_{\mathrm{s}}\right)$ symmetry, the pseudo-mirror plane lying on one of the benzene rings, $\mathrm{C}(2)-\mathrm{C}(7)$, and passing parpendicularly through the mid-point of one of the ethylenic bonds, C(19)-C(20), when compared to the molecule of Type A which has a crystallographic two-fold axis in the molecule. The macrocycle ring is more flat than the ring of Type $\mathrm{A}$. The maximum deviation of the ring atoms from the least-squares mean plane through all atoms in the molecule (thirty carbon atoms and twelve oxygen atoms) is $0.79 \AA$ for $\mathrm{C}(9)$ to one side and $0.62 \AA$ for $\mathrm{O}(11)$ to the opposite side of the mean plane. The molecular conformations are also specified by torsion angles given in Table IV and dihedral angles between the best planes calculated in Table V. Three equivalent benzene rings in the molecule are nearly pallarel to the mean plane of all atoms in the molecule, the dihedral angles of the benzene ring plane to the mean plane of all of atoms being $8.6^{\circ}$, $5.6^{\circ}$, and $7.9^{\circ}$. For Type $A$ the benzene rings are much inclined from the mean plane of the molecule. The corresponding ones for Type A are $3.4^{\circ}, 30^{\circ}$, and $30^{\circ}$. The flatness of the molecule is further illustlated by the dihedral angles between the benzene rings. For Type B the angles are $11.9^{\circ}, 5.0^{\circ}$, and $8.7^{\circ}$, whereas the angles for Type A are $26.8^{\circ}$ and $45.0^{\circ}$.

Three equivalent ethylene glylol chains have the gauche conformation and the conformational features of Type B are characterized in the torsion angles of these chains. The 


\section{Crystal Structure of Cyclic Trimer (Type B) of PET}

Table III. Principal intramolecular bond lengths $(\AA)$, and bond angles $\left({ }^{\circ}\right)$ with their e.s.d.'s in parentheses

\begin{tabular}{|c|c|c|c|c|c|}
\hline Bond lengths/ $/ \AA$ & & & & Average $^{a}$ & $\begin{array}{c}\text { Equivalent } \\
\text { average } \\
\text { value in } \\
\text { Type } A^{14}\end{array}$ \\
\hline $\mathrm{O}(1)-\mathrm{C}(1)$ & $1.35(1)$ & $\mathrm{O}(3) \mathrm{C}(8)$ & $1.34(1)$ & & \\
\hline $\mathrm{O}(5)-\mathrm{C}(11)$ & $1.34(1)$ & $\mathrm{O}(7)-\mathrm{C}(18)$ & $1.32(1)$ & & \\
\hline $\mathrm{O}(9)-\mathrm{C}(21)$ & $1.33(1)$ & $\mathrm{O}(11)-\mathrm{C}(28)$ & $1.34(1)$ & $1.337(4)$ & 1.337 \\
\hline $\mathrm{O}(2)-\mathrm{C}(1)$ & $1.20(1)$ & $\mathrm{O}(4)-\mathrm{C}(8)$ & $1.21(1)$ & & \\
\hline $\mathrm{O}(6)-\mathrm{C}(11)$ & $1.21(1)$ & $\mathrm{O}(8)-\mathrm{C}(18)$ & $1.20(1)$ & & \\
\hline $\mathrm{O}(10)-\mathrm{C}(21)$ & $1.22(1)$ & $\mathrm{O}(12)-\mathrm{C}(28)$ & $1.19(1)$ & $1.205(4)$ & 1.204 \\
\hline $\mathrm{O}(1) \mathrm{C}(30)$ & $1.42(2)$ & $\mathrm{O}(3)-\mathrm{C}(9)$ & $1.42(2)$ & & \\
\hline $\mathrm{O}(5)-\mathrm{C}(10)$ & $1.41(2)$ & $\mathrm{O}(7)-\mathrm{C}(19)$ & $1.44(2)$ & & \\
\hline $\mathrm{O}(9)-\mathrm{C}(20)$ & $1.43(2)$ & $\mathrm{O}(11)-\mathrm{C}(29)$ & $1.41(2)$ & $1.422(8)$ & 1.448 \\
\hline $\mathrm{C}(9)-\mathrm{C}(10)$ & $1.47(2)$ & $\mathrm{C}(19)-\mathrm{C}(20)$ & $1.50(2)$ & & \\
\hline $\mathrm{C}(29)-\mathrm{C}(30)$ & $1.47(2)$ & & & $1.48(1)$ & 1.487 \\
\hline $\mathrm{C}(1)-\mathrm{C}(2)$ & $1.49(1)$ & $C(5)-C(8)$ & $1.50(1)$ & & \\
\hline$C(11)-C(12)$ & $1.47(1)$ & $C(15)-C(18)$ & $1.46(1)$ & & \\
\hline $\mathrm{C}(21)-\mathrm{C}(22)$ & $1.46(1)$ & $C(25)-C(28)$ & $1.49(1)$ & $1.478(4)$ & 1.492 \\
\hline $\mathrm{C}(2)-\mathrm{C}(3)$ & $1.41(2)$ & $C(3)-C(4)$ & $1.42(2)$ & & \\
\hline$C(4)-C(5)$ & $1.41(1)$ & $C(5)-C(6)$ & $1.39(1)$ & & \\
\hline $\mathrm{C}(6)-\mathrm{C}(7)$ & $1.37(1)$ & $C(7)-C(2)$ & $1.36(1)$ & & \\
\hline$C(12)-C(13)$ & $1.42(1)$ & $\mathrm{C}(13)-\mathrm{C}(14)$ & $1.37(1)$ & & \\
\hline$C(14)-C(15)$ & $1.37(1)$ & $C(15)-C(16)$ & $1.44(1)$ & & \\
\hline$C(16)-C(17)$ & $1.43(1)$ & $\mathrm{C}(17)-\mathrm{C}(12)$ & $1.36(1)$ & & \\
\hline$C(22)-C(23)$ & $1.35(1)$ & $C(23)-C(24)$ & $1.41(1)$ & & \\
\hline$C(24)-C(25)$ & $1.38(1)$ & $C(25)-C(26)$ & $1.41(1)$ & & \\
\hline$C(26)-C(27)$ & $1.37(1)$ & $\mathrm{C}(27)-\mathrm{C}(22)$ & $1.40(1)$ & $1.393(2)$ & 1.384 \\
\hline Bond angles $/^{\circ}$ & & & & Average $^{a}$ & $\begin{array}{c}\text { Equivalent } \\
\text { average } \\
\text { value in } \\
\text { Type } \mathrm{A}^{14}\end{array}$ \\
\hline $\mathrm{O}(1)-\mathrm{C}(1)-\mathrm{C}(2)$ & $116.2(8)$ & $\mathrm{O}(3)-\mathrm{C}(8)-\mathrm{C}(5)$ & $112.7(8)$ & & \\
\hline $\mathrm{O}(5)-\mathrm{C}(11)-\mathrm{C}(12)$ & $115.7(8)$ & $\mathrm{O}(7)-\mathrm{C}(18)-\mathrm{C}(15)$ & $110.1(8)$ & & \\
\hline $\mathrm{O}(9)-\mathrm{C}(21)-\mathrm{C}(22)$ & $113.0(8)$ & $\mathrm{O}(11)-\mathrm{C}(28)-\mathrm{C}(25)$ & $114.0(8)$ & $113.6(3)$ & 112.1 \\
\hline $\mathrm{O}(2)-\mathrm{C}(1)-\mathrm{C}(2)$ & $122.7(9)$ & $\mathrm{O}(4)-\mathrm{C}(8)-\mathrm{C}(5)$ & $121.0(8)$ & & \\
\hline $\mathrm{O}(6)-\mathrm{C}(11)-\mathrm{C}(12)$ & $123.2(8)$ & $\mathrm{O}(8) \mathrm{C}(18)-\mathrm{C}(15)$ & $125.9(8)$ & & \\
\hline $\mathrm{O}(10)-\mathrm{C}(21)-\mathrm{C}(22)$ & $125.1(8)$ & $\mathrm{O}(12)-\mathrm{C}(28)-\mathrm{C}(25)$ & $125.3(8)$ & $123.9(3)$ & 124.5 \\
\hline $\mathrm{O}(1)-\mathrm{C}(1)-\mathrm{O}(2)$ & $120.4(9)$ & $\mathrm{O}(3)-\mathrm{C}(8)-\mathrm{O}(4)$ & $126.3(9)$ & & \\
\hline $\mathrm{O}(5)-\mathrm{C}(11)-\mathrm{O}(6)$ & $120.8(8)$ & $\mathrm{O}(7)-\mathrm{C}(18)-\mathrm{O}(8)$ & $121.6(9)$ & & \\
\hline $\mathrm{O}(9)-\mathrm{C}(21)-\mathrm{O}(10)$ & $121.8(9)$ & $\mathrm{O}(11)-\mathrm{C}(28)-\mathrm{O}(12)$ & 119.7(9) & $121.8(4)$ & 123.3 \\
\hline $\mathrm{C}(1)-\mathrm{O}(1)-\mathrm{C}(30)$ & 119.3(9) & $\mathrm{C}(8)-\mathrm{O}(3) \mathrm{C}(9)$ & $116.6(9)$ & & \\
\hline $\mathrm{C}(11)-\mathrm{O}(5)-\mathrm{C}(10)$ & $122.2(9)$ & $\mathrm{C}(18)-\mathrm{O}(7)-\mathrm{C}(19)$ & $107.5(9)$ & & \\
\hline $\mathrm{C}(21)-\mathrm{O}(9)-\mathrm{C}(20)$ & $120.1(9)$ & $\mathrm{C}(28)-\mathrm{O}(11)-\mathrm{C}(29)$ & 119.1(9) & $117.5(4)$ & 117.3 \\
\hline $\mathrm{O}(1)-\mathrm{C}(30)-\mathrm{C}(29)$ & $100.9(9)$ & $\mathrm{O}(3) \mathrm{C}(9)-\mathrm{C}(10)$ & 99.4(9) & & \\
\hline $\mathrm{O}(5)-\mathrm{C}(10)-\mathrm{C}(9)$ & $107.5(9)$ & $\mathrm{O}(7)-\mathrm{C}(19)-\mathrm{C}(20)$ & 93.6(9) & & \\
\hline $\mathrm{O}(9)-\mathrm{C}(20)-\mathrm{C}(19)$ & $106.6(9)$ & $\mathrm{O}(11)-\mathrm{C}(29)-\mathrm{C}(30)$ & $113.8(9)$ & $103.6(4)$ & 108.7 \\
\hline $\mathrm{C}(1)-\mathrm{C}(2)-\mathrm{C}(3)$ & $117.7(8)$ & $C(8)-C(5)-C(4)$ & $120.4(9)$ & & \\
\hline$C(11)-C(12)-C(13)$ & $122.5(9)$ & $C(18)-C(15)-C(14)$ & $123.3(9)$ & & \\
\hline$C(21)-C(22)-C(23)$ & $122.4(8)$ & $C(28)-C(25)-C(24)$ & $122.8(9)$ & $121.5(4)$ & 121.7 \\
\hline $\mathrm{C}(1)-\mathrm{C}(2)-\mathrm{C}(7)$ & $120.5(8)$ & $C(8)-C(5)-C(6)$ & $119.1(8)$ & & \\
\hline$C(11)-C(12)-C(17)$ & $116.8(9)$ & $C(18)-C(15)-C(16)$ & $117.6(8)$ & & \\
\hline
\end{tabular}


Table III. (continued)

\begin{tabular}{|c|c|c|c|c|c|}
\hline Bond angles $/^{\circ}$ & & & & Average $^{a}$ & $\begin{array}{c}\text { Equivalent } \\
\text { average } \\
\text { value in } \\
\text { Type } \mathrm{A}^{14}\end{array}$ \\
\hline $\mathrm{C}(21)-\mathrm{C}(22)-\mathrm{C}(27)$ & $112.3(8)$ & $C(28)-C(25)-C(26)$ & $120.4(9)$ & $117.8(3)$ & 118.5 \\
\hline $\mathrm{C}(3)-\mathrm{C}(2)-\mathrm{C}(7)$ & $121.8(9)$ & $C(4)-C(5)-C(6)$ & $120.4(8)$ & & \\
\hline $\mathrm{C}(13) \mathrm{C}(12)-\mathrm{C}(17)$ & $120.7(9)$ & $C(14)-C(15)-C(16)$ & $118.9(8)$ & & \\
\hline $\mathrm{C}(23)-\mathrm{C}(22)-\mathrm{C}(27)$ & $125.3(9)$ & $C(24)-C(25)-C(26)$ & $116.7(9)$ & $120.6(4)$ & 119.4 \\
\hline $\mathrm{C}(2)-\mathrm{C}(3)-\mathrm{C}(4)$ & $116.0(9)$ & $\mathrm{C}(3)-\mathrm{C}(4)-\mathrm{C}(5)$ & $120.9(9)$ & & \\
\hline$C(5)-C(6)-C(7)$ & $118.4(8)$ & $\mathrm{C}(6)-\mathrm{C}(7)-\mathrm{C}(2)$ & $122.4(8)$ & & \\
\hline$C(12)-C(13)-C(14)$ & $122.0(9)$ & $C(13)-C(14)-C(15)$ & $119.7(9)$ & & \\
\hline$C(15)-C(16)-C(17)$ & $120.9(8)$ & $C(16)-C(17)-C(12)$ & $117.7(8)$ & & \\
\hline$C(22)-C(23)-C(24)$ & $117.7(9)$ & $C(23)-C(24)-C(25)$ & $120.9(9)$ & & \\
\hline$C(25)-C(26)-C(27)$ & $125.0(8)$ & $C(26)-C(27)-C(22)$ & $114.0(8)$ & $119.6(2)$ & 120.3 \\
\hline
\end{tabular}

a The figure in parenthesis is the standard deviation of the mean, $\sigma=\bar{\sigma} / \sqrt{n} ; \bar{\sigma}$ is the mean of the individual standard deviations.

Table IV. Selected torsion angles $\left(^{\circ}\right)$ with their e.s.d.'s in parentheses

\begin{tabular}{lr}
\hline $\mathrm{O}(3)-\mathrm{C}(9)-\mathrm{C}(10)-\mathrm{O}(5)$ & $66.6(9)$ \\
$\mathrm{O}(7)-\mathrm{C}(19)-\mathrm{C}(20)-\mathrm{O}(9)$ & $80.7(8)$ \\
$\mathrm{O}(11)-\mathrm{C}(29)-\mathrm{C}(30)-\mathrm{O}(1)$ & $-56.4(9)$ \\
$\mathrm{C}(10)-\mathrm{C}(9)-\mathrm{O}(3)-\mathrm{C}(18)$ & $121.7(8)$ \\
$\mathrm{C}(9)-\mathrm{C}(10)-\mathrm{O}(5)-\mathrm{C}(11)$ & $137.4(8)$ \\
$\mathrm{C}(20)-\mathrm{C}(19)-\mathrm{O}(7)-\mathrm{C}(18)$ & $156.7(8)$ \\
$\mathrm{C}(19)-\mathrm{C}(29)-\mathrm{O}(9)-\mathrm{C}(21)$ & $150.2(8)$ \\
$\mathrm{C}(30)-\mathrm{C}(29)-\mathrm{O}(11)-\mathrm{C}(28)$ & $-104.4(9)$ \\
$\mathrm{C}(29)-\mathrm{C}(30)-\mathrm{O}(1)-\mathrm{C}(1)$ & $-110.8(8)$ \\
$\mathrm{O}(1)-\mathrm{C}(1)-\mathrm{C}(2)-\mathrm{C}(3)$ & $-11.2(9)$ \\
$\mathrm{O}(3)-\mathrm{C}(8)-\mathrm{C}(5)-\mathrm{C}(4)$ & $5.1(9)$ \\
$\mathrm{O}(5)-\mathrm{C}(11)-\mathrm{C}(12)-\mathrm{C}(13)$ & $-2.6(9)$ \\
$\mathrm{O}(7)-\mathrm{C}(18)-\mathrm{C}(15)-\mathrm{C}(14)$ & $-17.9(9)$ \\
$\mathrm{O}(9)-\mathrm{C}(21)-\mathrm{C}(22)-\mathrm{C}(23)$ & $-11.0(9)$ \\
$\mathrm{O}(11)-\mathrm{C}(28)-\mathrm{C}(25)-\mathrm{C}(24)$ & $178.6(8)$ \\
$\mathrm{O}(2)-\mathrm{C}(1)-\mathrm{C}(2)-\mathrm{C}(3)$ & $-174.5(8)$ \\
$\mathrm{O}(4)-\mathrm{C}(8)-\mathrm{C}(5)-\mathrm{C}(4)$ & $170.4(8)$ \\
$\mathrm{O}(6)-\mathrm{C}(11)-\mathrm{C}(12)-\mathrm{C}(13)$ & $179.9(8)$ \\
$\mathrm{O}(8)-\mathrm{C}(18)-\mathrm{C}(15)-\mathrm{C}(14)$ & $175.6(8)$ \\
$\mathrm{O}(10)-\mathrm{C}(21)-\mathrm{C}(22)-\mathrm{C}(23)$ & $-179.8(8)$ \\
$\mathrm{O}(12)-\mathrm{C}(28)-\mathrm{C}(25)-\mathrm{C}(24)$ & $-169.2(7)$ \\
$\mathrm{C}(2)-\mathrm{C}(1)-\mathrm{O}(1)-\mathrm{C}(30)$ & $165.8(7)$ \\
$\mathrm{C}(5)-\mathrm{C}(8)-\mathrm{O}(3)-\mathrm{C}(9)$ & $171.1(7)$ \\
$\mathrm{C}(12)-\mathrm{C}(11)-\mathrm{O}(5)-\mathrm{C}(10)$ & $153.1(6)$ \\
$\mathrm{C}(15)-\mathrm{C}(18)-\mathrm{O}(7)-\mathrm{C}(19)$ & $149.9(7)$ \\
$\mathrm{C}(22)-\mathrm{C}(21)-\mathrm{O}(9)-\mathrm{C}(20)$ & $176.1(6)$ \\
$\mathrm{C}(25)-\mathrm{C}(28)-\mathrm{O}(11)-\mathrm{C}(29)$ & \\
&
\end{tabular}

independent torsion angles are $66.6^{\circ}, 80.7^{\circ}$, and $-56.4^{\circ}$. These values are much deviated from the gauche $\left( \pm 60^{\circ}\right)$ than the values $\left(58.6^{\circ}, 62.5^{\circ}\right.$, and $58.6^{\circ}$ ) of Type A.

Dimensionally there are no significant differences between the three segments. The $\mathrm{CH}_{2}-\mathrm{CH}_{2}$ bond lengths between ethylene groups are in the range of $1.47(2)-1.50(2) \AA$ (mean value $1.48(1) \AA$ ). This significant shortening of the $\mathrm{C}_{s p} 3-\mathrm{C}_{s p} 3$ distances from the expected value of $1.537(5) \AA^{26}$ was systematically found in Type A, linear dimer of PET $^{18}$ and other $n$-methylene dibenzoate derivatives. ${ }^{27-30}$ The $\mathrm{O}-\mathrm{CH}_{2}$ bond lengths of ethylene glycol part of this molecule are also somewhat short (mean value $1.422(8) \AA$ ), when compared to $1.448 \AA$ for Type $\mathrm{A}$ and $1.442 \AA$ for linear dimer of PET. The $\mathrm{O}-\mathrm{CH}_{2}-\mathrm{CH}_{2}$ bond angles in the molecule with an average value of $103.6(4)^{\circ}$ are not so open as expected but the same as the values in linear dimer of PET $\left(104.2^{\circ}\right)^{18}$ and cyclic dimer of PBT $\left(103.8^{\circ}\right) .^{19}$

Figure 3 shows the environment of a molecule of Type B in the unit cell. The flat face of the molecule lies approximately perpendicular to the crystallographic $c$ axis. A molecule is surrounded by six neighbors forming a two dimmensional sheet perpendicular to the $c$ axis. Along the $c$ axis the molecules stack on top of each other forming infinite 
Crystal Structure of Cyclic Trimer (Type B) of PET

Table V. Least-squares best planes and displacement $(\AA)$ of the atoms from the planes ${ }^{\mathrm{a}}$

\begin{tabular}{|c|c|c|c|c|c|}
\hline Plane(1) & & Plane(2) & & Plane(3) & \\
\hline $\mathrm{C}(1)$ & $-0.027(8)$ & $\mathrm{C}(11)$ & $0.021(9)$ & $\mathrm{C}(21)$ & $0.031(9)$ \\
\hline $\mathrm{C}(2)^{\mathrm{a}}$ & $-0.013(8)$ & $C(12)^{a}$ & $0.009(9)$ & $C(22)^{a}$ & $0.023(9)$ \\
\hline $\mathrm{C}(3)^{\mathrm{a}}$ & $0.006(8)$ & $C(13)^{a}$ & $0.012(9)$ & $C(23)^{\mathrm{a}}$ & $0.010(9)$ \\
\hline$C(4)^{\mathrm{a}}$ & $-0.005(8)$ & $C(14)^{a}$ & $-0.016(9)$ & $C(24)^{a}$ & $-0.039(9)$ \\
\hline$C(5)^{a}$ & $0.012(8)$ & $C(15)^{a}$ & $-0.001(9)$ & $C(25)^{\mathrm{a}}$ & $0.010(9)$ \\
\hline$C(6)^{a}$ & $-0.015(8)$ & $C(16)^{a}$ & $0.016(9)$ & $C(26)^{a}$ & $0.019(9)$ \\
\hline $\mathrm{C}(7)^{\mathrm{a}}$ & $0.017(8)$ & $C(17)^{a}$ & $-0.020(9)$ & $C(27)^{\mathrm{a}}$ & $-0.026(9)$ \\
\hline $\mathrm{C}(8)$ & $-0.056(8)$ & $\mathrm{C}(18)$ & $0.105(9)$ & $\mathrm{C}(28)$ & $0.110(9)$ \\
\hline $\mathrm{O}(1)$ & $0.22(1)$ & $\mathrm{O}(5)$ & $0.09(1)$ & $\mathrm{O}(9)$ & $0.18(2)$ \\
\hline $\mathrm{O}(2)$ & $-0.06(1)$ & $\mathrm{O}(6)$ & $-0.15(1)$ & $\mathrm{O}(10)$ & $-0.04(2)$ \\
\hline $\mathrm{O}(3)$ & $-0.02(1)$ & $\mathrm{O}(7)$ & $-0.20(1)$ & $\mathrm{O}(11)$ & $-0.09(2)$ \\
\hline $\mathrm{O}(4)$ & $-0.14(1)$ & $\mathrm{O}(8)$ & $0.12(1)$ & $\mathrm{O}(12)$ & $0.15(2)$ \\
\hline $\mathrm{C}(9)$ & $0.24(1)$ & $C(10)$ & $-0.07(1)$ & $C(20)$ & $-0.39(2)$ \\
\hline$C(30)$ & $0.45(1)$ & $C(19)$ & $0.45(1)$ & $\mathrm{C}(29)$ & $0.07(2)$ \\
\hline$C(10)$ & $-0.96(1)$ & $\mathrm{C}(9)$ & $0.93(1)$ & $C(19)$ & $0.49(2)$ \\
\hline$C(29)$ & $-0.77(1)$ & $C(20)$ & $-0.47(1)$ & $C(30)$ & $1.32(2)$ \\
\hline \multicolumn{6}{|c|}{ Dihedral angles $\left({ }^{\circ}\right)$ between the planes } \\
\hline \multicolumn{4}{|c|}{ All atoms in the molecule and plane (1) } & \multicolumn{2}{|l|}{$8.6(5)$} \\
\hline \multicolumn{3}{|c|}{ All atoms in the molecule and Plane (2) } & & \multicolumn{2}{|l|}{$5.6(4)$} \\
\hline \multicolumn{3}{|c|}{ All atoms in the molecule and Plane (3) } & & \multicolumn{2}{|l|}{$7.9(4)$} \\
\hline \multicolumn{3}{|c|}{ Plane (1) and Plane (2) } & & \multicolumn{2}{|l|}{$11.9(5)$} \\
\hline \multicolumn{3}{|c|}{ Plane (1) and Plane (3) } & & \multicolumn{2}{|l|}{$5.0(5)$} \\
\hline \multicolumn{3}{|c|}{ Plane (2) and Plane (3) } & & \multicolumn{2}{|l|}{$8.7(5)$} \\
\hline
\end{tabular}

a Atoms included in the calculation of the plane.
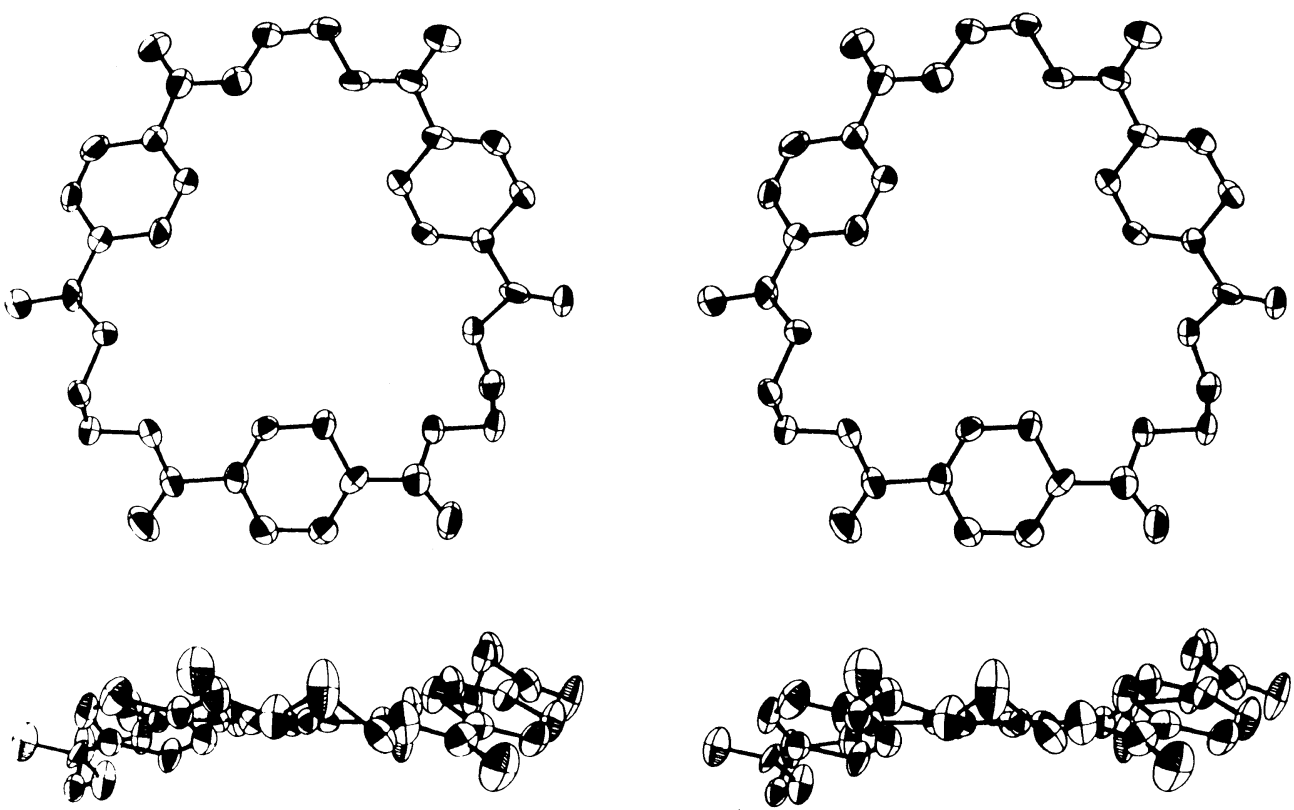

Figure 2. An ORTEP stereo drawing of the molecule of Type A determined by Haśek et al. ${ }^{14}$ Thermal ellipsoids are drawn at the $50 \%$ probability level. 

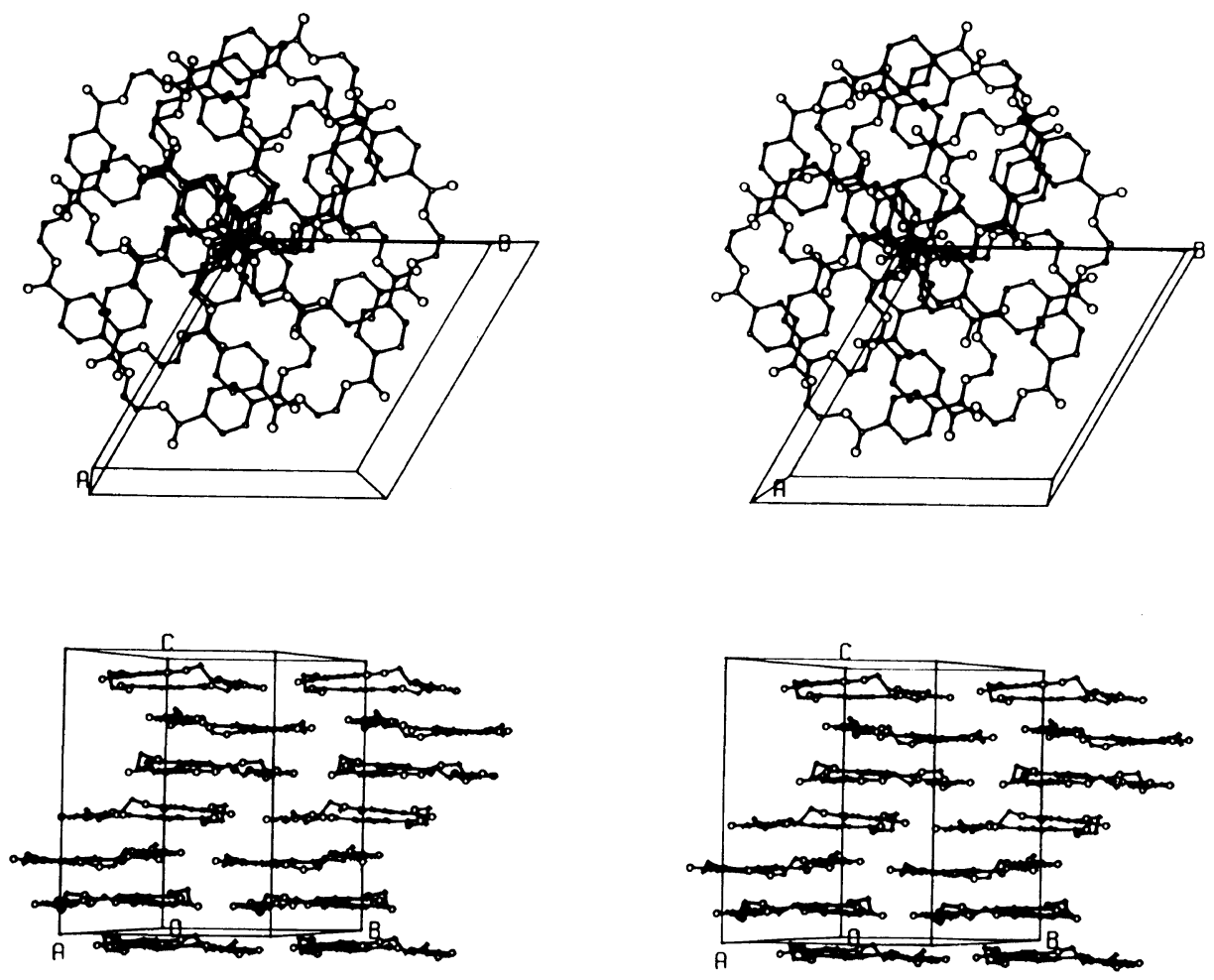

Figure 3. Crystal structure of Type B viewed along (top) and perpendicular (bottom) to the $c$ axis.
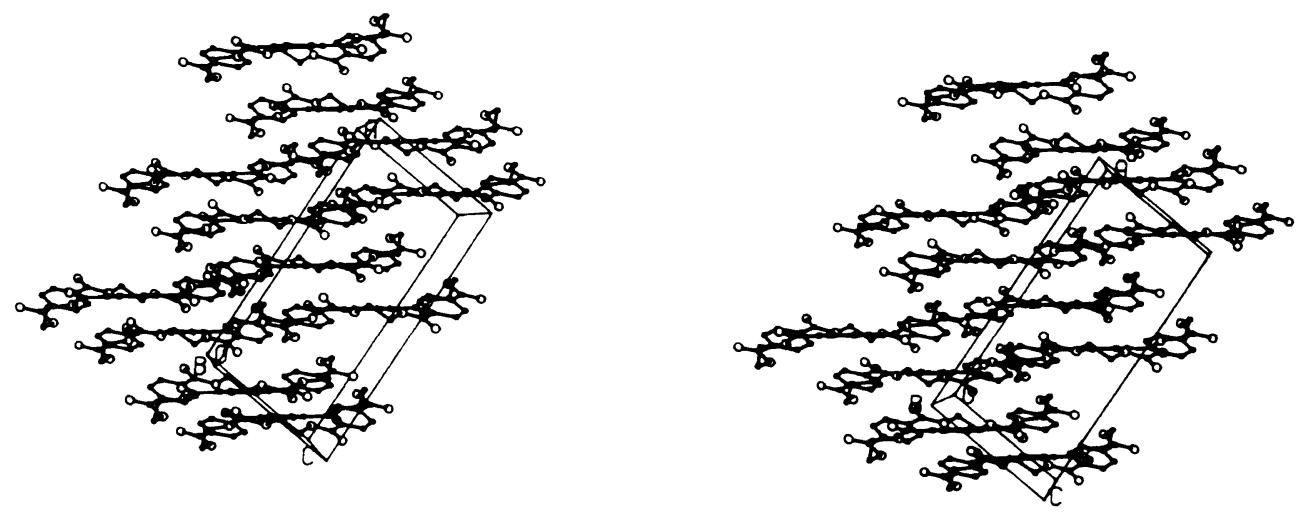

Figure 4. Crystal structure of Type A viewed along the $b$ axis, the direction of crystallographic 2-fold axis, and the $a$ and $c$ axes are inclined so that the molecules are arranged horizontally, the [10 $\overline{1}]$ direction being almost vertical.

spiral cylinders. The crystal structure of Type A determined by Haśek et al. ${ }^{14}$ is also described in Figure 4 in order to compare the molecular packing between the two modifications. The crystal was viewed along the $b$ axis, the direction of crystallographic 2-fold axis, and the $a$ and $c$ axes are inclined so that the molecules, packed in layers parallel to $(40 \overline{2})$ 
plane, are arranged horizontally and the [101] direction being almost vertical.

The volume per one molecule is $699.5 \AA^{3}$ for Type A and $702.7 \AA^{3}$ for Type B, respectively. These values, as expected, together with the differences in densities $\left(1.365 \mathrm{mg} \mathrm{m}^{-3}\right.$ for Type $A$ and $1.363 \mathrm{mg} \mathrm{m}^{-3}$ for Type B) suggest that the packing of the molecule of Type $B$ is looser than that of Type A.

Transparent Type A crystals having the centrosymmetric space group $C 2 / c$ turned opaque and transformed to Type B having the noncentrosymmetric space group $P 6_{1}$, when the crystals are raised above $200^{\circ} \mathrm{C}$. This means that the crystals of Type A break down first and then grow to the crystalline Type $\mathrm{B}$. These phenomena explain reasonably the powder $\mathrm{X}$-ray diffraction and thermal analysis data that the crystals of Type A become amorphous and then grow to the crystalline Type B. ${ }^{17}$

\section{REFERENCES}

1. V. Rossbach, Angew. Chem. Int. Ed. Engl., 20, 831 (1981).

2. S. D. Ross, E. R. Coburn, W. A. Leach, and W. B. Robinson, J. Polym. Sci., 13, 406 (1954).

3. B. Seidel, Z. Electrochem., 62, 214 (1958).

4. H. Zahn and B. Zeidel, Makromol. Chem., 29, 70 (1959).

5. I. Goodman and B. F. Nesbitt, Polymer, 1, 384 (1960).

6. G. Farrow, J. McIntosh, and I. M. Ward, Makromol. Chem., 38, 147 (1960).

7. G. L. Binns, J. F. Frost, F. S. Smith, and E.C. Yeadon, Polymer, 7, 583 (1966).

8. E. Ito and S. Okajima, J. Polym. Sci., Polym. Lett., 7, 483 (1969).

9. E. Ito and S. Okajima, Polymer, 12, 650 (1971).

10. D. R. Cooper and J. A. Semlyen, Polymer, 14, 185 (1973).
11. W. Berger and E. Tucek, Faserforsch. Textiltech., 25, 289 (1974).

12. R. Giuffria, J. Polym. Sci., 49, 427 (1961).

13. J. Haśek, J. Jećný, V. Langer, K. Huml, and P. Sedláćek, Acta Crystallogr., B36, 2698 (1980).

14. J. Haśek, J. Jećný, V. Langer, K. Huml, and P. Sedláćek, Acta Crystallogr., B38, 2710 (1982).

15. Y. Kitano and T. Ashida, Preprints, The 30th Annual Meeting of The Crystallographic Society of Japan, Tokyo, 1980, p P3-3.

16. Y. Kitano and T. Ashida, Polym. Prepr., Jpn., 30, 641 (1981).

17. Y. Kitano, M. Kashiwagi, and Y. Ebata, Bull. Chem. Soc. Jpn., 48, 1943 (1975).

18. Y. Kitano, A. Ishitani, and T. Inoue, Acta Crystallogr., C47, 363 (1991).

19. Y. Kitano, A. Ishitani, and T. Ashida, Polym. J., 23, 949 (1991).

20. Y. Kitano, A. Ishitani, and T. Ashida, Polym. J., 24, 783 (1992).

21. P. Main, S. E. Hull, L. Lessinger, G. German, J-P. Declercq, and M. M. Woolfson, "MULTAN 78, A System of Computer Programs for the Automatic Solution of Crystal Structure from X-ray Diffraction Data," University of York, England, and Louvain, Belgium, 1978.

22. "International Tables for X-Ray Crystallography," Vol. IV, Kynoch Press, Birmingham, England, 1974.

23. T. Ashida, "UNICS-Nagoya," The Computation Center, Nagoya University, 1981.

24. W. C. Hamilton, Acta Crystallogr., 12, 609 (1959).

25. C. K. Johnson, “ORTEP II," Report ORNL-5138, Oak Ridge National Laboratory, Oak Ridge, Tenn., 1976.

26. L. E. Sutton, "Tables of Interatomic Distances and Conformation in Molecules and Ions," Supplement 1956-59, London: The Chemical Society, 1965.

27. F. Brisse and S. Pérez, Acta Crystallogr., B32, 2110 (1976).

28. S. Pérez and F. Brisse, Acta Crystallogr., B33, 3259 (1977).

29. F. Brisse, N. Molhant, and S. Pérez, Acta Crystallogr., B35, 1825 (1979).

30. G. Bocelli and M. F. Grenier-Loustalot, Acta Crystallogr., B38, 2072 (1982). 